\title{
The vocational English teachers' personal competence and its implication on teaching and learning process
}

\author{
Mbarep Wicaksono, Ismail Petrus*, Soni Mirizon \\ Universitas Sriwijaya, South Sumatera, Indonesia
}

*corresponding author

Email: ismailpetrus@yahoo.com

\author{
Received: \\ Revised: \\ Accepted: \\ Published: \\ 22 November 2020 \\ 31 January 2021 \\ 27 February 2021 \\ 28 February 2021
}

\begin{abstract}
Personal competence is one of the four main competencies that teachers in Indonesia must possess. However, the literature has been still limited on the teacher's personal competence in the EFL context. Therefore, the present study aims to discover the application of vocational English teachers' personal competence and its implication on the teaching and learning process. To achieve the purpose of this study, a qualitative approach in a form of case study was employed. Two teachers of English consisting of one male and one female teacher participated in this study and shared their stories about the application of their personal competence at the school. A semi-structured interview became the instrument to obtain the data. The findings of this investigation indicated that the personal competence of EFL teachers was revealed from teachers' obedience towards regulation, the application of their religious values, the way they treat their students, the honesty and model they demonstrated, the teachers' maturity, wiseness, and assertiveness, the teachers' work ethic, the teachers' confidence in carrying out their duties and the pride towards their profession. The study also discussed how the teachers' personal competence might affect the teaching and learning process.
\end{abstract}

Keywords: Personal Competence; vocational English teachers; teaching and learning process

\section{INTRODUCTION}

Competence is a set of knowledge, skills, attitudes, and values that affect one's role, actions, achievements, and work. In other words, competence is a picture of what a person should do the job. Different cultural contexts influence the understanding of competence and this is especially important concerning the extent to which competence is defined by cultural literacy involving group identities such as race, gender, age, and class (Cseh, 2003). According to Spencer and Spencer (1993), competency is an underlying characteristic of a person related to the effectiveness of individual performance on the job or the fundamental characteristics of individuals who have a causal relationship or a cause and effect with the criteria referenced, effective or excellent or superior performance in the workplace or particular situations. They add competencies 
include: motives, traits, self-concepts, attitudes or values, content knowledge, or cognitive or behavioral skills - any individual characteristic that can be measured or counted reliably and displayed to differ significantly between superior and average performers, or between effective and ineffective performers. Other experts claim that competence is the basis of a personal characteristic that is the deciding factor in the success or failure of a person doing a job or in a particular circumstance (McClelland, 1993).

The personal competence of EFL teachers at the high school and vocational school level consist of several components. First, teachers must demonstrate actions based on the religious, legal, social and national cultural norms of Indonesia. Second, They should present themselves as honest, noble person and role model for students and society. Then, they must show themselves as a stable, mature, wise, and authoritative person. Next, the EFL teachers are required to demonstrate a good work ethic and responsibility, pride in being a teacher, and self-confidence. Finally, They have to apply the teacher's code of ethic (The Regulation of Ministry of Education of Indonesia, 2007)

There had been several previous studies discussing the importance of teacher personal competence at various levels of education. One of which was to conduct a correlational study at the junior high school level. Huda (2017) conducted a correlation study that examined the relationship between teacher personal competence and student learning motivation. The results of the study explained that there was a strong and significant correlation between personal competence and the student's learning motivation. Furthermore, Susetyowati and Susena (2017) also found in their study that the relationship between teacher personality competency and student learning achievement was positive and significant. Similiarly, Arisman et al. (2018) in their study stated that teacher personal competence influenced student' learning motivation.

Animah et al. (2020) did a correlation study to find out a relationship between personal teacher competence and student discipline. The study was conducted in an elementary school level setting with 30 participants as the sample. They discovered that there was a correlation between teacher personal competence and student's discipline. At vocational high school level, Darojah and Hadijah (2016) tried to find out the relationship between the teacher's personal competence and the learning motivation of the Office Administration Program students. The study found that the teacher's personal competence had a positive and significant influence on students' learning achievement through learning motivation. Theory-based studies were also conducted on the teacher personal competence. Fitriana (2019) discussed the role of teacher personal competence in the teaching and learning process by conducting a criticalconstructive analysis of Zakiah Darajat's work. Then, Dwintari (2017) analyzed the function and role of teacher personal competence towards civic education learning by reviewing relevant resources.

Based on the essetial role of teacher personal competence in teaching and learning activities described above, the question arises is that "How is the application of the vocational English teachers' personal competence and how it implicates the EFL teaching and learning process?" Unfortunately so far, there are still very few scientific studies that discuss personal competence in the 
context of EFL learning at a vocational school level. Therefore, given this discrepancy, this investigation aims to investigate and discuss the English teachers' personal competence and its implication on the teaching and learning process in a vocational school level.

\section{METHOD \\ Respondents}

Two EFL teachers were choosen as the respondents of this study. The specific strategy employed was criteria sampling (Miles \& Huberman, 1994). Each respondent met three criteria: (a) was a civil servant (b) taught at least 12 hours of English subject and (c) had one year or more teaching experience. Then, the two subjects was described using pseudonyms, Rome for the male respondent and Jane for the female respondent.

\section{Research design}

This study was conducted qualitatively in a form of case study. Qualitative research intends to discover data on the current status of phenomena that is identified with the prevailing circumstance at the time of the study. This examination was a subjective report as a contextual investigation plan. Adams et al. (2007) described that the purpose of qualitative research is to depict the phenomena and not to be particularly concerned with the arrangement of why something happens. It implies that there is no intercession from the investigations, hence the occasions being noticed are in the original circumstance (Bogdan \& Biklen, 1997).

Furthermore, a case study is an in-depth investigation of a single setting. Case study investigations are utilized for decision-making purposes in policymaking, best practice, or further investigations (Creswell \& Creswell, 2017). Case studies depend on an in-depth examination of an individual, group, or occasion to investigate the reasons for underlying principles. Therefore, this study employed a qualitative approach with a case study design to look for the personal competence of teachers of English based on their experience and the perspective of their associates. As verified by Frankel and Wallen (2009), a single-case design is utilized to a comprehensive understanding of a particular individual, group, circumstance, venture, or program.

\section{Data collection and analysis procedures}

To acquire in-depth stories of the teachers, a semi-structured interview was utilized (Denzin \& Lincoln, 2005). The author conducted one-on-one interview section with each respondent where they had to answer a preset open-ended questions. The interview consisted of 14 questions and centered around the respondents' personal competence application. It was held in the language with which the respondents were most comfortable, Bahasa Indonesia. The interview with each participant lasted approximately 60 minutes. The interview with the male participant was conducted face to face while the interview with the female one was done by WhatApps call. The writer also recorded the interview and noted in the form of memos to avoid missing the important details and help him understand the context of the participants' stories.

The analysis was conducted in three main steps. Initially, the author started the analysis by carefully transcribing the interview himself and 
reviewing the transcription repeatedly. Transcribing the data after each interview kept the transcription manageable and allowed him to begin reviewing them for the next step.

Furthermore, the transcription was coded in two cycles of coding. In the first cycle of coding, the initial coding was applied to breakdown the data into discrete parts, closely examining them, and comparing them for similarities and differences (Corbin \& Strauss, 2014). Next, focused coding was employed to search for the most frequent or significant codes to develop the most salient categories (Charmaz, 2006). Therefore, during this stage, the author grouped the similarly coded data, created several categories, and formed several important themes.

To this end, the emerging themes were used to construct the analysis. The themes and written transcripts were used to identify discrete experience segments of text in which the participants talk about a single event or experience. The writer reviewed the transcripts for places where there was a change from one experience segment to another. The writer reordered the segments to create a logical sequence or story. In the end, the writer reconstructed the result of the interview and explained the findings descriptively.

\section{FINDINGS AND DISCUSSION \\ The vocational English teachers' personal competence}

As the current study was conducted to investigate the vocational English teachers' personal competence, several salient categories including the teachers' obedience towards regulation, the application of their religious values, the way they treat their students, the honesty and model they demonstrated, the teachers' maturity, wiseness, and assertiveness, the teachers' work ethic, the teachers' confidence in carrying out their duties, and the pride towards their profession would be described in the following paragraphs.

\section{Teachers' obedience towards regulation}

Based on the data in this study, both respondents admitted that they always obeyed the rules when conducting their duties. Rome stated, "As a teacher, I definitely follow the regulation from the government." While Jane said, "As a civil servant, it is [my] duty to obey the rules set by the government." They were also very actively involved in maintaining the cleanliness the school environment where they worked. Rome, for example, used his position as one of the vice principal to support the cleanliness of the school environment. He said,

"Apart from teaching, I am the vice principal for facility and infrastructure affairs. One of my responsibilities is to provide cleaning facilities at school. Every quarter, we buy cleaning supplies such as brooms, mops and buckets for each class. Recently, I also initiated a collaboration with the Environment Agency $(B L H)$ to provide rubbish bins which are then distributed in several locations so that students can orderly and properly dispose their trash."

On the other hand, Jane focused on creating a comfortable learning environment for her students and tried to set an example for them. She said, "In the classroom, I always ask students to clean the surrounding and take out the trash. I also try to maintain my appearance and keep the hygiene of myself." 


\title{
The application of teachers' religious values
}

In the case of applying their religious values, both respondents conducted different practices. Humblely, Rome explained how he always started each teaching and learning activity by praying with all his students. He also closed the class by praying with them. Then, Rome also always motivated his students to be able to regularly read the Qur'an. He mentioned that,

\begin{abstract}
"The religious value that I usually do the most is that I always ask students to pray before and after studying. In the morning, I also always motivate them to recite Al-Quran so that the knowledge they learn will be blessed and useful for them."
\end{abstract}

Furthermore, Jane was a devout Muslim woman. She had always obeyed the teaching of Islam. For instance, the mother of two children always wore a long headscarf and well-covered dress according to islamic sharia. Furthermore, of all one's physical appearance, the 36-year-old woman believed that the best application of religious teachings was reflected in our behavior and attitudes to others. Therefore, Jane always attempted to be friendly and kind to anyone she met while carrying out his duties as a teacher. She said, "I always try to be friendly and kind every time I meet my students and meet with other teachers."

\section{The teachers' treatment towards students}

In terms of treating the students, Rome and Jane had something in common. Both teachers agreed that they must treat the students equally and believed that they had done their best effort to do so. Jane stated, "There should not be differences between one student and another. All students are our children that we must educate and foster." Similarly, Rome described how students background should not be a priviledge for students to get better service from the teachers, not should it be the reason they were mistreated in the classroom.

"We must not discriminate our students just because they come from poor families, different religious beliefs, or different intellectual levels. Our goal is the same, to educate them and shape their characters. Therefore, we must treat all students equally regardless their background." [Rome]

\section{Teachers' honesty and model}

In terms of demonstrating honesty, both respondents set different examples to the learners. Rome said that he always stressed to students to stay honest in doing tasks and carrying out exams.

\footnotetext{
"I want the character [honesty] to grow in them. Therefore, I tell them that it is okay to have a bad score once in a while. It is okay to fail because you still have time to improve. But when you are being dishonest, it will become your personality untill you grow old." [Rome]
}

On the other hand, Jane mentioned that her honestly was reflected in the way she scored and assessed the students' learning progress. She tried to be objective and fair to everyone of them. She said,

"I will give [students] the score that they deserve. When they perform well, they will receive high grade from me. But when they don't, there is nothing that can change the poor grade they will get. However, I still give them chances to improve their scores if they are willing to study and work harder." 
In the case of being a model for the students, both teachers argued that they had done their best effort to become a good example for them. However, they believed that they could improve their performance in the future.

\begin{abstract}
"As a teacher, I have made every effort to be a good example for my students at school. I try to be punctual to set an example for students about being discipline. I also encourage them to be honest by motivating them to study hard and avoid cheating during the exam. I try to be as fair as possible in giving my students grade. However, there are rooms for improvement to my performance. For instance, I cannot 100\% present in the classroom because I have other duties that require me to skip several classes. In the future, I will try to manage my time better so I can always be there for my students." [Rome]

"As a teacher, I have made every effort to be a good example for my students at school. I try to be punctual to set an example for students about being discipline. I also encourage them to be honest by motivating them to study hard and avoid cheating during the exam. I try to be as fair as possible in giving my students grade. However, there are rooms for improvement to my performance. For instance, I cannot 100\% present in the classroom because I have other duties that require me to skip several classes. In the future, I will try to manage my time better so I can always be there for my students." [Jane]
\end{abstract}

\title{
The teachers' maturity, wiseness and assertiveness
}

The teachers' maturity, wiseness and assertiveness were implicated through the way they provided punishment to students and how respectful the students to them. Rome emphatically said that he always punished his students who were late and did not comply with the school rules. Various punishments had been applied to his students. He said he always referred to the school rules and coordinated with the other school stakeholders in giving punishment.

"For minor violations, I always punish the students on the spot. For example, those who arrive late or are not properly dressed will have to clean the school yard before they can enter their classes. For serious violations, I usually work with counseling teacher and other school leaders to summon and talk to their parents. After three warning and teacher-parent meetings and no change in behavior shown, the students can be dismissed from the school." [Rome]

In giving punishment, Jane sought to avoid physical punishment. Physical punishment, she believed, could create trauma and made the students dislike the teacher punishing them. Therefore, she chose a more human punishment if she had to discipline her students. Counselling and giving advice were what she routinely did to students who committed violation. If possible, she preferred to tell her students what to do directly than punish them.

"The punishment that I give depends on the type of violation committed. For example, if a student does not dress neatly, I usually immediately tell him/or her] to tidy up his[or her] clothes. If they do not use proper school attributes, then I order them to look for these attributes before they can enter the class." [Jane]

The involvement of classroom teachers and parents was also no less important in educating students. Jane was aware of that. Therefore, when students were fighting, she would coordinate with the classroom teacher, the 
vice principal for the student affairs and the student's parents to find solutions of the problem.

Furthermore, As a young teacher, Rome admitted that he had not been fully respected by all students. He said that there were certain classes that put great respect to him. However, in some other classes, he still struggled to earn the respect of the students.

"I think I am in the process of being a respected teacher. I am a new teacher and still have many weaknesses in doing my duties. Of all the classes I teach, students in several classes listen to me and respect me highly. However, in some other classes where students have quite extreme attitudes and behaviors, I have to work a lot harder to gain their respect." [Rome]

Similarly, Jane also acknowledged that not all students listened to what she told them. She said, "there are also students who don't respect me and don't listen to me when I speak." Knowing that many students disrespected her, Jane did not blame herself. She believed it all happened because of the internal factors of the students.

\section{Teachers' work ethic}

A civil servant must demonstrate a good work ethic in carrying out his/her duties. Rome was aware of this. He always wanted to demonstrate a good work ethic by completing his tasks as a teacher such as teaching, making lesson plans, and assessing student assignments on time. Next, he also came on time to the class he was about to teach. He never left his class before the schedule he taught ended. Although he realized he sometimes could not teach while he was out of school due to other official duties. He said, "I never slack off and leave the school earlier than I should have. I always end class and go home as scheduled."

On the other hand, Jane accepted the fact that she must continue to improve her work ethic. In terms of providing services to the students, Jane mentioned that family was often a barrier for her. Having a husband and two children requireed her to choose between family and work, and family still seemed to be above all else. Jane was shy when she admitted that she was regularly not on time in for work. She said, "I often come late to the class and also have to leave my students during the teaching and learning process. I do so because I have to pick up my kid from school." Her tardiness would make the services that she should give to the students would not be as good as expected.

\section{Teachers' self-confidence}

Rome still seemed to lack of confidence in his English skills. This could be seen from his desire to conduct interviews in Bahasa Indonesia, not in English, the subject he must teach to the students. He said, "I feel more comfortable that way [using Indonesian language]." Jane should also possessed confidence in her ability. However, her decision to conduct the interview in Bahasa Indonesia, not English, indicated that she did not fully believe in the proficiency she had acquired. She stated,"[Speaking English during interview] makes me feel nervous." 
They also admitted that they use Indonesian language more often than English in delivering the material. Rome said, "I speak Indonesian language more often. I teach more fluently when using Indonesian language." In the similar sense, Jane admitted that she rarely used English in the classroom. She explained, "I almost never use English while teaching. I only use English when opening and closing the lessons."

\section{The pride of their profession}

Rome performed his duties as a teacher with pride. The profession he was in made him able to share many things with his students, especially the knowledge he had. He added,"By being a teacher, I can share knowledge to many people. Guiding, education and contributing to the success of my students are things I am really proud of." Furthermore, Jane explained that in the past she desperately wanted to be a nurse. However, fate took her to Universitas PGRI where she studied in English Education for four years. Although being a teacher was not her childhood dream, Jane said that she was very proud to eventually become a teacher. Through this profession, she got many opportunities to do good things. She added," I can help many children to be smart and share knowledge and information that will be useful for them in the future."

\section{The implication of the vocational English teachers' personal competence on the teaching and learning process}

The study also would like to describe the implication of personal competence of EFL teachers on the teaching and learning process. Based on the findings of this study, the EFL teachers described that they acted accordingly to the regulations set by both the government and the school. The teacher's attitude to the occuring regulations was very important for the development of the learners. Rules-abiding teachers would be great examples and create obedient students as well. On the contrary, teachers who did not obey the regulations would find it difficult to shape the characters of the learners. Therefore, many studies concluded that the students' behaviors were likely to reflect the behaviors of the teachers. The obedient teacher would stimulate the students' positive behaviors and reduce disobedience towards school regulation (Anderson \& Kincaid, 2005; Bracy, 2011; Way, 2011).

In terms of applying religious values, the EFL teachers demonstrated different pratices and perspectives. However, it was indispensable that they displayed themselves as the good example that the students could imitate and emulate. The application of religious values was an inseparable factor of the teachers' duties in the classroom. Those values occuring in the teacher's beliefs were very influential on the teacher's performance because they served as social and personal control for them in conducting their duties (Mardia, 2012; Ali, 2016). The application of religious values also provided a positive impact on the formation of student attitudes because religious merits could help teachers to establish character values which become a part of national education goal (Arif, 2017).

Furthermore, both respondents explained in the findings that they had done their best to treat all students fairly and equally. How teachers treat students is another important factor that can affect the teaching and learning process. The way teachers treats students has a profound impact on the 
teacher-student relationship. When the teachers treats the students well and fairly, a positive relationship would be established. Such positive relationship could affect students not only in learning processes and outcomes but it also influenced far beyond the classroom (Önder et al., 2020; Claessens et al., 2017; Alvarez, 2007; Roorda et al., 2013). Then, the teacher's treatment towards the students also greatly affects their emotion, personality and quality of thinking during the process of learning (Blazar \& Kraft, 2017; Uitto et al., 2018; Urhahne, 2015).

The next aspect that is influencial to the teaching and learning process is teachers' honesty. Based on the findings, it was stated that the two EFL teachers demonstrated honesty in their action. Rome instilled honesty to his students through encouragement, while Jane showed her honesty from the way she graded her students' learning progress. Honesty becomes an inseparable part of the teacher's duty in education. It is very important for teachers to apply honesty at the school especially in evaluating the learning outcomes of the students (McClain et al., 2018). Honesty is also necessary to maintain the integrity of teachers in teaching learning activities (Suud et al., 2019; Nillsen, 2005). Furthermore, honesty and integrity that is applied by the teacher and taught to the students could prevent them from cheating (Cavico \& Mujtaba, 2009). Furthermore, the efforts from Rome and Jane in becoming role models for their students are an integral part of the teaching and learning process. Lumpkin (2008) said that learners needed to imitate educators who were effortlessly genuine, trusting, fair, respectful, and responsible in their actions. Teachers must be able to serve as role models who teach and demonstrate character and moral virtues (Heid \& Kelehear, 2007; Lickona, 2009; Lunenberg et al., 2007). Therefore, when students has regarded the teachers as their role models, positive transformation would emerge towards their behavior (Hughes $\&$ Chen, 2011), learning style (Yildirim et al., 2008) and interest towards the subjects (Bashir et al., 2014).

Another factor in the teachers' personal competence that affected the teaching and learning process was how the teachers disciplined their students through the rules applied and the punishments given. Both respondents that they provided humane and educative punishment to the students. The forms of punishment given were suitable with the misconducts or misobediences that the students committed. Punishment is sometimes required in teaching and learning activities to reduce students' disobedience towards the regulation and create orders in the school environment. It is a powerful strategy for remediating individual's mischief and subsequently improving school orders if it commensurates with the offence committed. Punishment would teach learners the connection between their actions and the result or accountability for their misconducts. What Rome and Jane did was a humane and educative form of punishment that was considerably proper with the offences. They avoided providing physical or corporal punishment because they considered it as ineffective and could adversely affect their students. Corporal punishment could cause decreased self-esteem and self-efficacy, somatic complaints, increased anxiety, negative changes in personality or depression, and school dropout (Greydanus et al., 2003). Moreover, there was no evidence that corporal punishment could produce better result academically (Ahmad et al., 2014). They 
instead caused the rise of school dropouts and provoked resentments from students and created pro-violent behavior (Tharps, 2003). Therefore, Rome and Jane preferred to provide advice to those who committed violations at the school. Arigbo and Adeogun (2018) also suggested that schools must take their time and effort to providing counselling and guidance as a prevention measurement rather than punishing the offenders.

Furthermore, the way students respected the teachers also supported the success of teaching and learning process. According to Parse (2006), respect refers to the acknowledgement of presence and is regard something or someone worthy of admiration. In other word, it was the endorsement and recognition of the self by others. Darwall (2010) purposed two types of respect: recognition and appraisal respect. Recognition respect was considered as the respect paid to something by nature of its essence, and was exemplified by the affirmation of an individual because of their humanity, or for the role they possess. On other hand, appraisal respect referred to a human being's abilities or esteem for their achievements. Based on the findings, both teachers claimed that they were respected by some students. However, there were also some learners that acted less respectful to them during the learning process. They acknowledged that the respect shown by students to teachers affected the progress of teaching and learning process. Students who respected them would be happy to listen to the directions and information the teachers conveyed. On the other hand, students who disrespect them tended to ignore every material and lesson delivered. Therefore, as the embodiment of a good personal competence, teachers must be respected by learners because respect is an important factor that can help teachers in learning and teaching activities (Martin, 2006; Niemiec \& Ryan, 2009; O'Grady et al., 2011).

In teacher personal competence, there were also other aspects such as teachers' work ethic, self-confidence, and pride of their profession that could not be ruled out. The findings showed that the two teachers demonstrated their work ethic dissimilarly. Rome always showed his work ethic by coming to school and class on time. He was trying to leave the classroom as scheduled. On the other hand, Jane had a hard time doing the same thing. She faced work-family conflict in conducting her duties. Her role as a mother and wife often overshadowed her duties as a teacher. Work ethic is essential for the teaching and learning process. Teachers are required to demonstrate a good work ethic because it provides positive impacts on various sectors in the world of education. First, the teacher's work ethic is able to improve the effectiveness of learning (Patmawati et al., 2018), improve the effectiveness of teacher performance (Marlina, 2015) and improve students' learning performance positively (Loisa \& Setyanto, 2016).

Next, based on the findings, both respondents realized that they did not have enough self-confidence towards their ability in English. As EFL teachers, they used Indonesian language more than they used English during the teaching and learning progress. Though, self-confidence is a very important factor for teachers because it could increase the comfort and ease on carrying out teaching duties (Åkerlind, 2003), influence teachers' performance (Sriyono, 
2018), improve student's learning and self-confidence (Mbuva, 2016), and was useful for teacher's development (Hativa, 2000; Sadler, 2013).

In the end, pride of the teacher profession also contributes to the teaching and learning process. Based on the findings, both respondents claimed they were really proud of their profession. The pride of their profession became the biggest motivation for them to do their best for the students. Teachers should possesses a sense of pride of their profession because pride will boost their performance and encourage them to do more (Tracy \& Robins, 2004; Goudarzi et al., 2011). Pride would also bring teachers to conduct their duties with better efficiency, commitment and productivity (Nigli \& Joseph, 2017).

\section{CONCLUSION}

Two vocational English teachers gave their stories about the values of Teacher Personal Competence that they had applied at school. They explained the components in personal competence that they implemented including the teachers' obedience towards regulation, the application of their religious values, the way they treat their students, the honesty and model they demonstrated, the teachers' maturity, wiseness and assertiveness, the teachers' work ethic, the teachers' confidence in carrying o ut their duties, and the pride towards their profession. This study also discusses the indications and implications that may occur from the values in the teacher's personal competence to the success of the teaching and learning process. In the end, there are several aspects that must be improved by the vocational English teachers such as work ethic and self-confidence.

\section{REFERENCES}

Adams, J., Khan, H. T. A., Raeside, R., \& White, D. I. (2007). Research methods for graduate business and social science students. SAGE Publications India Pvt Ltd. http://dx.doi.org/10.4135/9788132108498.

Ahmad, I., Said, H., Awang, Z., Yasin, M., Hasan, Z., \& Mansur, S. (2014). Effect of selfefficacy on the relationship between corporal punishment and school dropout. Review of European Studies, 6. https://doi.org/10.5539/res.v6n1p196.

Åkerlind, G. S. (2003). Growing and developing as a university teacher--variation in meaning. Studies in Higher Education, 28(4), 375-390. https://doi.org/10.1080/0307507032000122242.

Ali, N. (2016). Penerapan nilai-nilai ajaran islam dalam pembelajaran umum. ISTIQRA', $3(2)$, 207-216. https://jurnal.umpar.ac.id/index.php/istiqra/article/view/252/226.

Alvarez, H. K. (2007). The impact of teacher preparation on responses to student aggression in the classroom. Teaching and Teacher Education, 23(7), 1113-1126. https://doi.org/10.1016/j.tate.2006.10.001.

Anderson, C. M., \& Kincaid, D. (2005). Applying behavior analysis to school violence and discipline problems: Schoolwide positive behavior support. The Behavior Analyst, 28(1), 49-63. https://doi.org/10.1007/BF03392103.

Animah, S., Hidayat, S. H., \& Nulhakim, L. (2020). The correlation of teacher personality 
competence with discipline of student grade 6. Primary: Jurnal Pendidikan Guru Sekolah Dasar, 9(4), 520-526. http://dx.doi.org/10.33578/jpfkip.v9i4.7981.

Arif, H. (2017). Peranan guru dalam pendidikan karakter di era globalisasi. Jurnal Pendidikan Islam Pendekatan Interdisipliner, 1(2), 69-79. https://doi.org/10.36915/jpi.v1i2.21.

Arigbo, P. O., \& Adeogun, T. F. (2018). Effect of punishment on students academic performance: An empirical study of secondary school students in Ikwuano Abia state, Nigeria. International Journal of Applied Research and Technology, 7(10), 5258.

Arisman, Getteng, A. R., \& Nuryamin, N. (2018). Pengaruh kompetensi kepribadian guru terhadap motivasi belajar peserta didik MTSn 2 Bone Kabupaten Bone. Jurnal Diskursus Islam, 6(3), 418-443. https://doi.org/10.24252/jdi.v6i3.6544.

Bashir, S., Bajwa, M., \& Rana, S. (2014). Teacher as a role model and its impact on the life of female students. International Journal of Research-Granthaalayah, 1(1), 920.

http://citeseerx.ist.psu.edu/viewdoc/download?doi=10.1.1.673.9231\&rep=rep1\& type $=$ pdf.

Blazar, D., \& Kraft, M. A. (2017). Teacher and teaching effects on students' attitudes and behaviors. Educational Evaluation and Policy Analysis, 39(1), 146-170. https://doi.org/10.3102/0162373716670260.

Bogdan, R., \& Biklen, S. K. (1997). Qualitative research for education. Allyn \& Bacon.

Bracy, N. L. (2011). Student perceptions of high-security school environments. Youth \& Society, 43(1), 365-395. https://doi.org/10.1177/0044118X10365082.

Cavico, F. J., \& Mujtaba, B. G. (2009). Making the case for the creation of an academic honesty and integrity culture in higher education: reflections and suggestions for reducing the rise in student cheating. American Journal of Business Education (AJBE), 2(5), 75-88. https://doi.org/10.19030/ajbe.v2i5.4072.

Charmaz, K. (2006). Constructing grounded theory: A practical guide through qualitative analysis. Sage.

Claessens, L. C. A., van Tartwijk, J., van der Want, A. C., Pennings, H. J. M., Verloop, N., den Brok, P. J., \& Wubbels, T. (2017). Positive teacher-student relationships go beyond the classroom, problematic ones stay inside. The Journal of Educational Research, 110(5), 478-493. https://doi.org/10.1080/00220671.2015.1129595.

Corbin, J., \& Strauss, A. (2014). Basics of qualitative research: Techniques and procedures for developing grounded theory. Sage publications.

Creswell, J. W., \& Creswell, J. D. (2017). Research design: Qualitative, quantitative, and mixed methods approaches. Sage publications.

Cseh, M. (2003). Facilitating learning in multicultural teams. Advances in Developing Human Resources, 5(1), 26-40. https://doi.org/10.1177\%2F1523422302239181.

Darojah, N. R., \& Hadijah, H. S. (2016). An analysis of the influence of personal competence of teachers with motivation to learn as an intervening variable on achievement of administrative office student grade $\mathrm{X}$. Jurnal Pendidikan Manajemen Perkantoran, 1(1), 115-125.

Darwall, S. (2010). Sentiment, care, and respect. Theory and Research in Education, 8(2), 153-162. https://doi.org/10.1177\%2F1477878510368618.

Denzin, N. K., \& Lincoln, Y. S. (2005). Introduction: The discipline and practice of 
qualitative research. In The Sage Handbook of Qualitative Research (pp. 1-30). Sage Publications Ltd. https://psycnet.apa.org/record/2005-07735-001.

Dwintari, J. W. (2017). Kompetensi kepribadian guru dalam pembelajaran pendidikan kewarganegaraan berbasis penguatan pendidikan karakter. Jurnal Pendidikan Kewarganegaraan, $7(2)$, 51-57. http://dx.doi.org/10.20527/ kewarganegaraan.v7i2.4271.

Fitriana, S. (2019). Peran kepribadian guru dalam proses belajar mengajar (analisis kritis-konstruktif atas pemikiran Zakiah Daradjat). Jurnal Muslim Heritage, 4(2), 281-300.

Frankel, J. R., \& Wallen, N. E. (2009). Single-subject research. In How to design and evaluate research in education.(7th ed.) (pp. 301-329). McGraw-Hill.

Goudarzi, K., Llosa, S., Orsingher, C., Gouthier, M. H. J., \& Rhein, M. (2011). Organizational pride and its positive effects on employee behavior. Journal of Service Management, 22(5), https://doi.org/https://doi.org/10.1108/09564231111174988.

Greydanus, D. E., Pratt, H. D., Spates, C. R., Blake-Dreher, A. E., Greydanus-Gearhart, M. A., \& Patel, D. R. (2003). Corporal punishment in schools: Position paper of the society for adolescent medicine. Journal of Adolescent Health, 32(5), 385-393. http://dx.doi.org/10.1016/S1054-139X(03)00042-9.

Hativa, N. (2000). Becoming a better teacher: A case of changing the pedagogical knowledge and beliefs of law professors. Instructional Science, 28(5), 491-523. https://link.springer.com/chapter/10.1007/978-94-010-0593-7_13.

Heid, K. A., \& Kelehear, Z. (2007). The challenge to care in schools: An alternative approach to education. Studies in Art Education, 48(4), 412-415. https://doi.org/10.2307/25475845.

Huda, M. (2017). Kompetensi kepribadian guru dan motivasi belajar siswa. Jurnal Penelitian, 11(2), 237-266. http://dx.doi.org/10.21043/jupe.v11i2.3170.

Hughes, J. N., \& Chen, Q. (2011). Reciprocal effects of student-teacher and studentpeer relatedness: Effects on academic self efficacy. Journal of Applied Developmental Psychology, 32(5), 278-287. https://doi.org/10.1016/j.appdev.2010.03.005.

Lickona, T. (2009). Educating for character: How our schools can teach respect and responsibility. Bantam.

Loisa, R., \& Setyanto, Y. (2016). Penyingkapan diri melalui internet di kalangan remaja (studi komunikasi antar pribadi). Jurnal Komunikasi, 6(3), 31-43. http://dx.doi.org/10.24912/ik.v6i3.38.

Lumpkin, A. (2008). Teachers as role models teaching character and moral virtues. Journal of Physical Education, Recreation \& Dance, 79(2), 45-50. https://doi.org/10.1080/07303084.2008.10598134.

Lunenberg, M., Korthagen, F., \& Swennen, A. (2007). The teacher educator as a role model. Teaching and Teacher Education, 23(5), 586-601. https://doi.org/10.1016/j.tate.2006.11.001.

Mardia, M. (2012). Penerapan nilai-nilai ajaran islam dalam pembelajaran mata pelajaran umum di madrasah tsanawiyah negeri (MTsN) Tinambung Kabupaten Polewali Mandar. Jurnal Pendidikan Islam Pendekatan Interdisipliner, 1(2), 59-68. https://doi.org/https://doi.org/10.36915/jpi.v1i2.20.

Marlina, M. (2015). Pengaruh motivasi, disiplin, dan etos kerja terhadap kinerja guru 
SLTA negeri Di Kecamatan Baolan Kabupaten Tolitoli. E-Jurnal Katalogis, 3(7), 153-162.

Martin, M. (2006). School matters: The report of the task force on student behaviour in second level schools. REACH: Journal of Inclusive Education in Ireland, 2O(1), 5-11.

Mbuva, J. (2016). Exploring Teachers' self-esteem and its effects on teaching, students' learning and self-esteem. Journal of Higher Education Theory and Practice, 16(5), 59-60.

McClain, L., Gulbis, A., \& Hays, D. (2018). Honesty on student evaluations of teaching: Effectiveness, purpose, and timing matter! Assessment \& Evaluation in Higher Education, 43(3), 369-385. https://doi.org/10.1080/02602938.2017.1350828.

McClelland, D. C. (1993). Intelligence is not the best predictor of job performance. Current Directions in Psychological Science, 2(1), 5-6. https://doi.org/10.1111/1467-8721.ep10770447.

Miles, M. B., \& Huberman, A. M. (1994). Qualitative data analysis: An expanded sourcebook. Sage.

Niemiec, C. P., \& Ryan, R. M. (2009). Autonomy, competence, and relatedness in the classroom: Applying self-determination theory to educational practice. Theory and Research in Education, 7(2), 133-144. https://doi.org/10.1177/1477878509104318.

Nigli, K. S., \& Joseph, B. (2017). Pride in work and job embeddedness among the frontline employees in hotel industry. Rajagiri Management Journal, 11(2), 51-62.

Nillsen, R. (2005). The concept of integrity in teaching and learning. Journal of University Teaching \& Learning Practice, 2(3), 85-93.

O'Grady, E., Hinchion, C., \& Mannix McNamara, P. (2011). The importance of respect in teaching and learning: Perspectives of final year pre-service teachers in a regional university in Ireland. European Journal of Teacher Education, 34(4), 501518. https://doi.org/10.1080/02619768.2011.592978.

Önder, A., Gülay Ogelman, H., \& Göktaş, İ. (2020). Examining the predictive effect of teacher-child relationship on young children's self-perception. Early Child Development and Care, 1-8. https://doi.org/10.1080/03004430.2020.1759574.

Parse, R. R. (2006). Feeling respected: A parse method study. Nursing Science Quarterly, 19(1), 51-56. https://doi.org/10.1177/0894318405283553.

Patmawati, Yunus, M., Devilla, R., \& Yahya, M. (2018). Pengaruh manajemen kelas dan etos kerja guru terhadap efektivitas pembelajaran di SMP Negeri 1 Parepare. Jurnal Ilmiah Pena: Sains Dan Imu Pendidikan, 1(2), 9-20. https://ojs.stkippi.ac.id/index.php/jip/article/view/147.

Peraturan Menteri Pendidikan Nasional Republik Indonesia Nomor 16 Tahun 2007 Standar Kualifikasi Akademik dan Kompetensi Guru. 4 Mei 2007. Kementerian Pendidikan Nasional Republik Indonesia. Jakarta.

Roorda, D. L., Koomen, H. M. Y., Thijs, J. T., \& Oort, F. J. (2013). Changing interactions between teachers and socially inhibited kindergarten children: An interpersonal approach. Journal of Applied Developmental Psychology, 34(4), 173-184. https://doi.org/10.1016/j.appdev.2013.03.002.

Sadler, I. (2013). The role of self-confidence in learning to teach in higher education. Innovations in Education and Teaching International, 50(2), 157-166. https://doi.org/10.1080/14703297.2012.760777. 
Spencer, L. M., \& Spencer, S. M. (1993). Competence at work: Models for superior performance. John Wiley \& Sons, Inc.

Sriyono, H. (2018). The influence of self-confidence on the performance of social science teachers in the New Kebayoran sub-district of South Jakarta. International Journal of Research Science \& Management, 5(6), 1-5. https://doi.org/10.5281/zenodo.1285533.

Susetyowati, T., \& Susena, S. (2017). Hubungan kompetensi kepribadian guru dengan prestasi belajar siswa di SMP Muhammadiyah 2 Kalasan. Jurnal Citizenship: Media Publikasi Pendidikan Pancasila Dan Kewarganegaraan, 3(1), 1-10.

Suud, F. M., Sutrisno, S., \& Madjid, A. (2019). Educational honesty: The main philosophical value in school. TARBIYA: Journal of Education in Muslim Society, 6(2), 141-154. https://doi.org/doi:10.15408/tjems.v6i2. 11769.

Tharps, L. L. (2003). The truth about spanking. Essence, 33(1), 22-30.

Tracy, J., \& Robins, R. (2004). Putting the self into self-conscious emotions: A Theoretical Model. Psychological Inquiry, 15(2), 103-125. https://doi.org/10.1207/s15327965pli1502_01.

Uitto, M., Lutovac, S., Jokikokko, K., \& Kaasila, R. (2018). Recalling life-changing teachers: Positive memories of teacher-student relationships and the emotions involved. International Journal of Educational Research, 87, 47-56. https://doi.org/https://doi.org/10.1016/j.ijer.2017.11.004.

Urhahne, D. (2015). Teacher behavior as a mediator of the relationship between teacher judgment and students' motivation and emotion. Teaching and Teacher Education, 45, 73-82. https://doi.org/10.1016/j.tate.2014.09.006.

Way, S. M. (2011). School discipline and disruptive classroom behavior: The moderating effects of student perceptions. The Sociological Quarterly, 52(3), 346-375. https://doi.org/10.1111/j.1533-8525.2011.01210.x.

Yildirim, O., Acar, A. C., Bull, S., \& Sevinc, L. (2008). Relationships between teachers' perceived leadership style, students' learning style, and academic achievement: A study on high school students. Educational Psychology, 28(1), 73-81. https://doi.org/10.1080/01443410701417945.

Conflict of Interest Statement: The authors declare that the research was conducted in the absence of any commercial or financial relationships that could be construed as a potential conflict of interest.

Copyright (C) 2021 Wicaksono, Petrus, and Mirizon. This is an open-access article distributed under the terms of the Creative Commons Attribution License (CC BY). The use, distribution or reproduction in other forums is permitted, provided the original author(s) and the copyright owner(s) are credited and that the original publication in this journal is cited, in accordance with accepted academic practice. No use, distribution or reproduction is permitted which does not comply with these terms. 